\section{Australian Journal of \\ Crop Science}

AJCS 14(03):545-550 (2020)

doi: 10.21475/ajcs.20.14.03.p2325

\title{
Composition and antimicrobial activity of essential oil of yarrow (Achillea millefolium L.)
}

\author{
Paulo Sergio Daniel ${ }^{1}$, Emerson Luiz Botelho Lourenço ${ }^{1}$, Rayane Monique Sete da $\mathrm{Cruz}^{2}$, Carlos Henrique \\ De Souza Gonçalves ${ }^{3}$, Luiz Renato Marques Das Almas ${ }^{3}$, Jaqueline Hoscheid ${ }^{4}$, Camila da Silva ${ }^{5}$, Ezilda \\ Jacomassi ${ }^{1}$, Liberato Brum Junior ${ }^{1}$, Odair Alberton* ${ }^{1}$
}

${ }^{1}$ Programa de Pós-graduação em Plantas Medicinais e Fitoterápicos na Atenção Básica. Laboratório de Pesquisa Pré Clínica de Produtos Naturais e Bioativos, Universidade Paranaense (UNIPAR), Praça Mascarenhas de Moraes, 4282, Umuarama, PR, Brazil

${ }^{2}$ Programa de Pós-graduação em Agronomia, Universidade Estadual de Maringá (UEM), Avenida Colombo, 5790, Maringá, PR, Brazil

${ }^{3}$ Química industrial; Universidade Paranaense (UNIPAR), Praça Mascarenhas de Moraes, 4282, Umuarama, PR, Brazil

${ }^{4}$ Curso de Farmácia; Universidade Paranaense - UNIPAR, Campus Toledo, Curso de Farmácia. Avenida Parigot de Souza, 3636, Toledo, PR, Brazil

${ }^{5}$ Departamento de Tecnologia; Universidade Estadual de Maringá (UEM), Avenida Ângelo Moreira da Fonseca, 1800, Umuarama, PR, Brazil

*Corresponding author: odair@prof.unipar.br; oalberton@yahoo.com.br

\section{Abstract}

The medicinal plant yarrow (Achillea millefolium L.) belongs to the Asteracea family. It is being used in the pharmacological, food, and cosmetic industry. The economic importance of yarrow resides in its essential oil (EO). This plant is used in traditional medicine as the EO has properties which range from antibacterial, antifungal, anti-inflammatory, anti-oxidant and antitumor activities. The objective of this study was to identify chemical components and EO content of yarrow, as well as its antimicrobial activity against some micro-organisms in vitro. The fresh leaves were collected in a morning in October (2018) at the UNIPAR Medicinal Plants Garden, Umuarama-Paraná State, Brazil. The EO was obtained by hydrodistillation of the modified Clevenger type. After that, the content $(\mathrm{m} / \mathrm{m} \%)$ was calculated. The chemical composition of the EO was identified by gas chromatography/mass spectrometry (GC/MS). The minimal inhibitory concentration (MIC), minimal bactericidal concentration (MBC) and minimal fungicidal concentration (MFC) were determined by a microdilution method in 96-well microtitre plates and effect of EO was assessed on four micro-organisms (Candida albicans, Staphylococcus epidermidis, Escherechia coli and Klebsiella pneumoniae). The EO content (yield) in the plant shoots was $0.4 \%$ (four grams of EO kg ${ }^{-1}$ of plant fresh shoots) and presented 20 chemical compounds such as $\alpha$ farnesene $(31.66 \%)$, followed by chamazulene (17.17\%), $\beta$-caryophyllene $(10.27 \%)$ and sabinene $(8.77 \%)$. The majority class was hydrocarbon sesquiterpene with $74.29 \%$. The antimicrobial activity tests showed that the EO had low antimicrobial activity against the analyzed species with MIC for all species above $1.5 \mathrm{mg} \mathrm{mL}^{-1}$. It was concluded that the EO content was $0.4 \%$. The major component was $\alpha$-farnesene (31.66\%) and EO presented low MIC.

Keywords: $\alpha$-farnesene; asteracea; hydrodistillation, medicinal plant; microdilution.

Abbreviations: EO_essential oil; GC/MS_Gas chromatography/mass spectrometry; IZD_inhibition zone diameter; MIC_minimal inhibitory concentration; MBC_minimal bactericidal concentration; MFC_minimal fungicidal concentration; UNIPAR_Universidade Paranaense.

\section{Introduction}

The family Asteraceae (formerly Compositae) is one of the largest in the angiosperms, possessing about 1,500 genera, of which approximately 180 are in Brazil and consist of around 23,000 species, arranged in 4 subfamilies and 17 tribes (Bremer, 1994). Important representatives of the family, include the sunflower (Helianthus annus), of great agricultural and economic importance; chamomile (Matricaria chamomilla), used as anti-spasmodic; arnica (Arnica montana) anti-inflammatory, and yarrow, used with 
various medicinal properties, all of which have diverse biological activities (Sweetman, 2002).

The genus Achillea is one of the most important genera of the Asteraceae family, composed of more than 100 species with significant ethnopharmacology (Mohammadhosseini et al., 2017) that grow wild in different parts of the world (Ali et al., 2017).

The Latin name Achillea is derived from the Greek hero Achilles, who used it in one of his battles to heal his king. The specific epiphyte millefolium means a thousand leaves (yarrow), which is allusive to a large number of leaves that it owns (Lorenzi and Matos, 2002). It is native to Europe, South Australia, North America, and Asia and has adapted to the climate of Brazil, and is considered the most known species of the genus Achillea (Candan et al., 2003).

The Achillea millefolium L. (yarrow) has been used in the pharmacological industry for the production of herbal medicines, using the stem, leaves and flowers for medicinal purposes (Ali et al., 2017). In addition to the pharmacological industry, the plant is also used in the cosmetic industry in photo protective production, food as an ingredient for the manufacture of liqueurs and flavorings and also in landscaping as an ornamental plant (Nadim et al., 2011).

The yarrow plant is 30 to $50 \mathrm{~cm}$ tall. It is an aromatic, perennial, dark green herb with hard and rhizomatous stems. It has abundant leaves, long, pinnate and pink or white flowers. The plant grows wild along highways, in fields and pastures. Its flowering time is in spring when cultivated. In nature, it flowers twice a year in the months of May to September (Lorenzi and Matos, 2002).

Yarrow has been popularly used in the treatment of hemorrhage, ulcers, diarrhea, cancer, tumors, warts, leukorrhea, influenza, pneumonia, etc. It is also considered as an abortive, contraceptive, anti-hematic, healing, analgesic, anti-inflammatory, antipyretic, anthelmintic, antibacterial, antifungal, antitumor, antioxidant and antioedematous (Sweetman, 2002).

In Brazil, this plant is used in traditional medicine, due to its antibacterial, anti-tumor, anti-fungal, anti-inflammatory, anti-inflammatory, antihypertensive, antihistaminic, rheumatic pain, fever, respiratory infections, ulcers and cicatrizant attributes (Salvagnini et al., 2006). Therefore, this vegetable has been the target of several evaluations regarding the biological properties of its essential oil (EO) (Lorenzi and Matos, 2002). The popular use of the species is made through the leaves and branches of cultivated plants, prepared as infused or macerated, with the benefits being related to its antipyretic, analgesic, anti-influenza, antitussive, anti-hemorrhoidal and headache relief properties (Battisti et al., 2013; Messias et al., 2015). According to the First Supplement of the Phytotherapeutic Form of the Brazilian Pharmacopoeia (2018), yarrow is used in the form of tincture. It helps for the relief of dyspeptic symptoms, flatulence, inflammation such as choleretic and antispasmodic.

The economic importance of yarrow is associated, in particular, with the production of EO, which can be used both for the manufacture of pharmaceuticals and for the cosmetics industry (Ali et al., 2017). The major chemical components of the plant's EO are terpenes, which are responsible for its medicinal properties. However, these are synthesized in small amounts by the plant (Nadim et al., 2011).

The EO is characterized by being a volatile oily-looking substance at room temperature with a strong and pleasant aroma present in the various parts of a plant (root, stem, leaf, flower, fruit, seeds and bark). Volatility is its main characteristic, and distinguishes it from a fixed oil, which are mixtures of lipid substances, usually obtained from seeds. It is also highly unstable in the presence of light, heat, moisture, air and metals (Simões et al., 2004).

It is used to obtain aromatic compounds with a pleasant odor for application in perfumes, fragrances and cosmetics, as well as its therapeutic, insecticidal, fungistatic and bactericidal properties, besides the possibility of being a precursor of molecules (Andrade et al., 2009).

The EO of yarrow is composed mainly of monoterpenes (30$80 \%)$, sesquiterpenes $(8-62 \%)$ and in smaller amounts by other compounds (1-3\%), such as alcohols, esters, aldehydes and norcarotenoids. The main monoterpene compounds in the oil are 1,8 cineole, camphor, borneol, $\alpha$ and $\beta$-pinene and $\alpha$-terpineol. The major sesquiterpenes are $\beta$ caryophyllene, $\beta$-cubebene, $\alpha$-farnesene and Chamazulene (Orav et al., 2006; Salvagnini et al., 2006; Nadim et al., 2011; Kindlovits and Németh, 2012; Ali et al., 2017).

The antibacterial activity of EOs is considerably sensitive to factors such as concentration, family, genus, plant species of interest, climatic conditions of the sampling area and the polarity of the extraction solvents, as well as the bacterial strains used. In most studies, it is evaluated by inhibition zone diameter (IZD) and minimum inhibitory concentration (MIC) approaches (Mohammadhosseini et al., 2016a, 2016b). Some studies use minimal bactericidal concentration (MBC) or bacteriostatic concentration, but both agree closely with the general meaning of the term MIC (Burt, 2004).

Antimicrobial resistance is considered a global health problem, which compromises the effectiveness of antibiotics and prevents the treatment of common infections. It may be related to excess use of bactericidal, bacteriostatic or antifungal drugs, where lack of knowledge and selfmedication promote the induction of this factor. Therefore, there is a need for the discovery of new substances from natural sources, including plants (Sartoratto et al., 2004; Oliveira et al., 2013; Ali et al., 2017).

Consequently, the objective of this study was to identify the chemical components and content of yarrow EO, as well as its antimicrobial activity against some micro-organisms in vitro.

\section{Results and Discussion}

\section{Essential oil content}

The EO content of the yarrow found in the present study was $0.4 \%$. According to the literature, the EO content may range from $0.1 \%$ to $1 \%$ (De Sant'Anna et al., 2009). Stevanovic et al. (2015), observed the EO content of three populations of the species in different soil types, and the value was between $0.32 \%$ and $1.01 \%$. Almadiy et al. (2016) found that the yarrow species presented the lowest yield of $0.21 \%$ of the other species of the genus studied. 
Table 1. Chemical composition (\%) of Achillea millefolium essential oil.

\begin{tabular}{|c|c|c|}
\hline Compounds & $\begin{array}{l}\mathrm{a} R T \\
\end{array}$ & ${ }^{\mathrm{b}} \%$ \\
\hline Monoterpenes & & 17.54 \\
\hline Monoterpenes hydrocarbons & & 11.76 \\
\hline Sabinene & 9.495 & 8.77 \\
\hline$\beta$-Myrcene & 10.062 & 0.78 \\
\hline$\delta$-Limonene & 11.380 & 0.88 \\
\hline ү-Terpinene & 12.466 & 1.33 \\
\hline Monoterpenes Oxygenated & & 5.06 \\
\hline Eucalyptol & 11.459 & 1.96 \\
\hline Terpinen-4-ol & 16.887 & 2.24 \\
\hline$\alpha$-Terpineol & 17.419 & 0.86 \\
\hline Sesquiterpenes & & 79.60 \\
\hline Sesquiterpenes hydrocarbons & & 74.29 \\
\hline Copaene & 23.536 & 0.72 \\
\hline$\beta$-Caryophyllene & 25.043 & 10.27 \\
\hline$\beta$-Copaene & 25.291 & 0.99 \\
\hline Humulene & 26.097 & 3.73 \\
\hline Bicyclogermacrene & 27.522 & 5.84 \\
\hline$\alpha$-Farnesene & 27.820 & 31.66 \\
\hline$\delta$-Amorphene & 28.288 & 3.91 \\
\hline Chamazulene & 34.493 & 17.17 \\
\hline Sesquiterpenes Oxygenated & & 5.31 \\
\hline Caryophyllene oxide & 30.083 & 0.66 \\
\hline$\alpha$-cadinol & 32.240 & 4.65 \\
\hline No identified compounds & & 1.99 \\
\hline $\mathrm{NI}$ & 26.175 & 1.18 \\
\hline $\mathrm{NI}$ & 27.400 & 0.81 \\
\hline Others compounds & & 1.58 \\
\hline Palmitic acid & 41.840 & 1.58 \\
\hline
\end{tabular}

${ }^{a} \mathbf{R T}$ - Retention time. ${ }^{{ }^{\%} \%}$ - percentage area. $\mathbf{N I}$ - No identified compounds

\begin{tabular}{lll}
\multicolumn{2}{l}{ Table 2. Bacterial and bacteriostatic activity of Achillea millefolium essential oil (EO) against species of micro-organisms. } \\
\hline Micro-organisms & EO Concentration ( $\mathrm{mg} \mathrm{mL}^{-1}$ ) & Microbial Activity \\
\hline Candida albicans (ATCC 10231) & $\geq 37.5$ & Fungistatic \\
Staphylococcus epidermidis (ATCC 12228) & 150 & Bacteriostatic \\
Escherechia coli (ATCC 25922) & 150 & Bacteriostatic \\
Klebsiella pneumoniae (ATCC 13883) & 150 & Bactericidal \\
\hline
\end{tabular}

The results reported above corroborate with Rohloff et al. (2000) findings, who observed that the content of the OE and its quality depended on the genetics, climate and soil conditions, as well as the age of the plant, the part studied and harvesting period.

\section{Chemical identification of essential oil and antimicrobial activity}

The chromatographic analysis of the EO of the yarrow aerial parts in the present study showed that among the chemical compounds found, the sesquiterpenes were the major compounds, totaling $79.60 \%$. Among them, $\alpha$-farnesene (31.66\%), chamazulene (17.17\%) and $\beta$-caryophyllene $(10.27 \%)$ showed the highest concentrations followed by the sabinene $(8.77 \%)$, which is a monoterpene hydrocarbons corresponding to $11.76 \%$ of the total chemical compounds (Table 1).

The results of the antimicrobial action tests on S. epidermidis and E. coli presented bacteriostatic activity at a concentration of $150 \mathrm{mg} \mathrm{mL}^{-1}$ of EO. Study of $K$. pneumoniae showed bactericidal activity at the concentration of $150 \mathrm{mg}$
$\mathrm{mL}^{-1}$ of EO. The yeast $C$. albicans at the concentration of 37.5 $\mathrm{mg} \mathrm{mL}^{-1}$ of EO demonstrated a fungistatic profile. However, all micro-organisms tested in the present study showed a low antimicrobial activity. The antimicrobial and fungistatic response of yarrow EO to species of micro-organisms was expressed in MIC values (Table 2).

The sesquiterpene, $\alpha$-farnesene and its $\beta$-farnesene isomer have the potential to act as an antimutagen. It is also considered one of the constituents responsible for the antichemostatic activity observed in the EO of chamomile (Ayoughi et al., 2011).

Chamazulene is a sesquiterpene responsible for the bluish coloration of EO. This component is derived from matricin, a terpenic lactone, which in the hydrodistillation process is converted into chamazulene. It has bactericidal, fungicidal, anti-inflammatory and antioxidant properties (Singh et al., 2011).

The $\beta$-caryophyllene is a bicyclic sesquiterpene responsible for the anti-inflammatory, anti-edema, antitumor, bactericidal, insecticidal and spasmolytic properties (Carneiro et al., 2010). 
Sabinene is a bicyclic monoterpene which can be used as a fat solvent (cholesterol) and clots in the arteries, and as an expectorant against infections and analgesic. It has been applied in the preparation of various artificial EO (Arctander, 2000).

According to Pino et al. (1998), the EO of yarrow cultivated in Cuba had a different chemical composition in comparison with previous studies, particularly the absence of chamazulene, but was rich in $20 \%$ chamazulene oxide and also showed $5.2 \%$ of $\beta$-caryophyllene concentration and the sabinene was $5.4 \%$, although $\alpha$-farnesene was not found.

In a study conducted in Russia, Orth et al. (1999), collected the plant in four different geographic regions, in two consecutive years 1996 and 1997. They found a variation of 46.2 to $73 \%$ of chamazulene, 1.5 to $11.7 \%$ of $\beta$ caryophyllene and a small concentration of $\alpha$-farnesene $(0.1$ to $0.6 \%$ ) in the chemical composition of the yarrow EO. Among the hydrocarbon monoterpenes identified, the main was the sabinene (4.7 to $7.5 \%$ ).

In Turkey, Candan et al. (2003) found $0.4 \%$ of $\beta$ caryophyllene and $2.8 \%$ of sabinene, but did not find chamazulene and $\alpha$-farnesene. Thus, this presents a chemical composition different from the studies observed in another geographic origin.

According to Orav et al. (2006), we observed that the 19 yarrow EO samples collected from different European countries had a strong characteristic of odor and blue color, the intensity of which depended on the amount of chamazulene formed by the degradation of matricin during distillation. These researchers found a high concentration of $42 \%$ chamazulene and $12.5 \% \beta$-caryophyllene. In this study, Sabinene was the second hydrocarbon monoterpene with the highest concentration (11.7\%), while $\alpha$-farnesene was not observed.

In Brazil, a study by De Sant'Anna et al. (2009) identified chamazulene in EO that reached highest concentration of $42.15 \%$ followed by the sabinene with $19.72 \%$, and $\beta$ caryophyllene (4.44\%).

In Servia, Stevanovic et al. (2015) evaluated the content and composition of the EO of three yarrow populations under different saline soil conditions. Chamazulene (15.84\%) was the main chemical component found, following by sabinene (5.29\%).

In Egypt, Almadiy et al. (2016), evaluated four species of the genus Achillea. The main chemical component was the chamazulene (26.2\%), the sabinene $(9.2 \%)$ and $\beta$ caryophyllene (5.9\%).

Thus, according to the European Pharmacopoeia, the composition of the yarrow EO is rich in chamazulene, $\beta$ pinene, sabinene, 1,8 -cineole and $\beta$-caryophyllene. This corroborates with the present study, in which chamazulene (17.17\%), $\beta$-caryophyllene (10.27\%) and sabinene (8.77\%) are among the four major compounds.

Orav et al. (2006) observed that the composition of EO depends on the number of chromosomes, tetraploid $(4 n)$, hexaploid $(6 n)$ and octaploid $(8 n)$, which justifies the different concentrations of chamazulene found in several studies with yarrow. Furthermore, Nemeth (2005) confirmed that composition of the $\mathrm{OE}$ is dependent on the part of the plant extracted, the geography, season of the year and also the number of chromosomes.
According to the literature, antimicrobial activity is considered strong for MIC values between 0.05 and $0.50 \mathrm{mg}$ $\mathrm{mL}^{-1}$, moderate activity between 0.6 and $1.50 \mathrm{mg} \mathrm{mL}^{-1}$ and a weak activity above $1.50 \mathrm{mg} \mathrm{mL}^{-1}$ (Sartoratto et al., 2004; Duarte et al., 2005). In the present study, the antimicrobial action tests of yarrow EO showed that two of the four of micro-organisms, $S$. epidermidis and $E$. coli, had bacteriostatic activity at the concentration of $150 \mathrm{mg} \mathrm{mL}^{-1}$. $K$. pneumoniae showed bactericidal activity at the concentration of $150 \mathrm{mg} \mathrm{mL}^{-1}$ and $C$. albicans at the concentration of $37.5 \mathrm{mg} \mathrm{mL}^{-1}$, demonstrating a fungistatic profile. However, all microbial species tested presented low antimicrobial activity, according to the criteria mentioned above.

According to Tzakou et al. (2001), eucalyptol (1.8-cineol) and camphor are well-known chemical substances with their pronounced antimicrobial potentials. Among the chemical compounds identified, eucalyptol only presented $1.96 \%$, which may be one of the factors of the low antimicrobial activity of the evaluated EO (Tables 1 and 2).

According to Candan et al. (2003), yarrow EO exhibited moderate activity against $S$. pneumoniae, Clostridium perfringens and $C$. albicans and weak activity against Mycobacterium smegmatis, Acinetobacter Iwoffii and Candida krusei. The inhibition of growth of test microorganisms ranged from $4.5 \mathrm{mg} \mathrm{mL}^{-1}$ to $72.0 \mathrm{mg} \mathrm{mL}^{-1}$, with the lowest MIC value against $S$. pneumoniae, $C$. perfringens and $C$. albicans at $4.5 \mathrm{mg} \mathrm{mL}^{-1}$. Again, weak antimicrobial activity was observed.

Duarte et al. (2005) verified the fungistatic activity for the $C$. albicans species of 35 medicinal plants commonly used in Brazil. They found an EO content of the species yarrow $0.19 \%$ and MIC of $0.25 \mathrm{mg} \mathrm{mL}^{-1}$, considered as high antimicrobial activity in that study.

Almadiy et al. (2016) verified that the EOs of the species Achillea santolina and $A$. millefolium had moderate to weak antibacterial activity with a diameter of the zone of inhibition ranging from 6.0 to $16.5 \mathrm{~mm}$.

Ribeiro et al. verified (2010) that the yarrow EO MIC varied from 0.312 to $1.25 \mathrm{mg} \mathrm{mL}^{-1}$ for $C$. albicans, presenting strong to moderate activity against this micro-organism.

According to the systematics reviews carried out by Mohammadhosseini et al. (2017) and Ali et al., (2017) the chemical composition of EOs and extracts of the various species of the genus Achillea and their biological activities in most of the species present as moderate to strong antimicrobial activity. However, according to the three studies mentioned above the yarrow EO presented a weak to moderate profile against antimicrobial activity

Materials and methods

\section{Extraction and determination of essential oil content}

The fresh leaves of the yarrow plant were collected at the beginning of October, 2018, from the Medicinal Plants Garden of UNIPAR (Paranaense University), Umuarama Campus (Paraná, Brazil) located at Latitude 2346'11.34 " and Longitude $53^{\circ} 16^{\prime} 41.78$ "and washed in running water. In the laboratory of the Paranaense University, $100 \mathrm{~g}$ of the aerial plant part were ground in an industrial blender with 
the addition of 1 liter of deionized water by reverse osmosis. Subsequently, hydrodistillation of the sample was initiated using a modified Clevenger type EO distiller (Morelli et al., 2017). The extraction time was approximately 3 hours, counted after the first drop of dark blue EO was formed.

The EO was removed from the apparatus with hexane, filtered with anhydrous sodium sulfate $\left(\mathrm{Na}_{2} \mathrm{SO}_{4}\right)$ and kept in flasks opened at $-20{ }^{\circ} \mathrm{C}$ until total evaporation of hexane. Then, the content $(\mathrm{m} / \mathrm{m} \%)$ was calculated, taking into account the aerial plant part mass versus the EO mass extracted.

\section{Chemical identification of essential oil}

The chemical identification of the yarrow EO was performed at the State University of Maringá - UEM (Campus Umuarama) by gas chromatography coupled to mass spectrometry (GC/MS) using GC-MS QP 2010 SE (Shimadzu). $10 \mu \mathrm{L}$ of the samples were diluted in $1000 \mu \mathrm{L}$ of dichloromethane (anhydrous) before being injected onto a SH-RTX-5MS (Shimadzu, 5\% phenylmethylsiloxane, $30 \mathrm{mx}$ $0.25 \mathrm{~mm}$ id, $0.25 \mu \mathrm{m}$ ) column using a self-sampler (Shimadzu

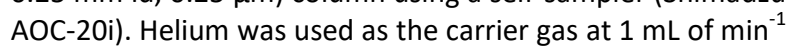
flow with a split ratio of 2:1 and amount of sample injected $(1 \mu \mathrm{L})$. The column temperature was initially programmed at $40^{\circ} \mathrm{C}$, heating at $8{ }^{\circ} \mathrm{C} \mathrm{min}^{-1}$ to reach the final temperature of $300{ }^{\circ} \mathrm{C}$. The interface temperatures of the injector and the GC-MS interface were maintained at $250{ }^{\circ} \mathrm{C}$. Mass spectra were recorded at $70 \mathrm{eV}$ with a mass range of $\mathrm{m} / \mathrm{z} 50$ to 550 amu and the EO chemical compounds were identified based on library and GC-MS Postrun Analysis software.

\section{Determination of minimum inhibitory concentration}

Minimal Inhibitory Concentration (MIC) was determined by the serial dilution technique in duplicate 96-well microplates, following a methodology previously described by Oliveira et al. (2009). MIC was performed against the micro-organisms and respective ATCCs: Candida albicans (10231), Staphylococcus epidermidis (12228), Escherichia coli (25922) and Klebsiella pneumoniae (13883).

Initially $90 \mu \mathrm{L}$ of nutrient broth was added to the wells containing 96 wells. Then $90 \mu \mathrm{L}$ of $150 \mathrm{mg} \mathrm{mL}^{-1}$ EO was added to the second orifice of each line and homogenized three times. Then, $90 \mu \mathrm{L}$ transferred to the third hole and so on until the eleventh hole was reached, after which $90 \mu \mathrm{L}$ homogenization were discarded.

From the first to the eleventh column, $10 \mu \mathrm{L}$ of the bacterial suspensions in sterile water on the 0.5 scale of McFarland were added to the microplate wells. For the positive control, the first column (broth and bacterium) was used. For the negative control, the twelfth column (containing only broth) was used.

Microplates were incubated at $37{ }^{\circ} \mathrm{C}$ for $24 \mathrm{~h}$ (for bacteria) and $28{ }^{\circ} \mathrm{C}$ for $48 \mathrm{~h}$ (fungi) under aerobic conditions. After that time, $20 \mu \mathrm{L}$ of the $2 \%$ TTC (2,3,5-triphenyltetrazolium chloride) developer was added to all the holes in the plates and incubated for another 2 hours. At the end of the incubation, the appearance of a reddish color indicated the bacterial multiplication, whereas those holes that remained colorless did not present such activity (Oliveira et al., 2009).

\section{Determination of fungi and bactericidal and bacteriostatic activity}

In Petri dishes containing Mueller Hinton Agar medium for bacteria and Sabouraud Dextrose Agar for fungi, the plating of the colorless wells was performed. After incubation for 24 $\mathrm{h}$ at $37{ }^{\circ} \mathrm{C}$, the reading was performed. The growth of bacterial and fungal colonies indicated that the concentration evaluated had a fungi or bacteriostatic effect, whereas the absence of growth indicated the fungi or bactericidal effect of EO (Oliveira et al., 2009).

\section{Conclusion}

The yarrow EO content was $0.4 \%$ and EO chromatographic analysis detected 20 chemical compounds. The hydrocarbon sesquiterpene class showed the majority of $74.29 \%$. The most abundant chemical compound was $\alpha$-farnesene (31.66\%), followed by chamazulene (17.17\%), $\beta$ caryophyllene (10.27\%) and sabinene (8.77\%). The EO presented low antimicrobial activity against the analyzed species $C$. albicans, S. epidermidis, E. coli and K. pneumoniae with MIC for all species above $1.5 \mathrm{mg} \mathrm{mL}^{-1}$. This low antimicrobial activity is probably because, among the chemical compounds known in the literature for their pronounced antimicrobial potentials, eucalyptol was the only one present with a low concentration of $1.96 \%$.

\section{Acknowledgements}

The authors thank the Universidade Paranaense - UNIPAR for supporting the research. Rayane Monique Sete da Cruz thanks PROSUP/CAPES for the scholarship. Odair Alberton, Emerson L. Botelho Lourenço and Camila da Silva acknowledge a research fellowship from the CNPq (National Council of Scientific and Technological Development).

\section{References}

Ali SI, Gopalakrishnan B, Venkatesalu V (2017) Pharmacognosy, phytochemistry and pharmacological properties of Achillea millefolium L.: A Review. Phytother Res. 31: 1140-1161.

Almadiy AA, Nenaah GE, Assiuty BAA, Moussa EA (2016) Chemical composition and antibacterial activity of essential oils and major fractions of four Achillea species and their nanoemulsions against foodborne bacteria. LWTFood Sci Technol. 69: 529-537.

Andrade EHA, Guimaraes EF, Maia JGS (2009) Variabilidade química em óleos essenciais de espécies de Piper da Amazônia. 22. ed. Belém: FEQ/UFPA, 448p.

Arctander S (2000) Perfume and flavor chemicals (aroma chemicals). Allured Publishing Corporation: USA.

Ayoughi F, Marzegar M, Sahari MA, Naghdibadi H (2011) Chemical compositions of essential oils of Artemisia dracunculus L. and endemic Matricaria chamomilla L. and an evaluation of their antioxidative effects. J Agr Sci Tech. 13: 79-88.

Battisti C, Garlet TMB, Essi L, Horbach RK, Andrade A, Badke MR. (2013) Plantas medicinais utilizadas no município de Palmeira das Missões, RS, Brasil. R Bras Bioci. 11: 338-348. 
BRASIL (2008) Farmacopéia Brasileira. Agência Nacional de Vigilância Sanitária. Brasília: Anvisa, 546p.

Bremer K (1994) Asteraceae - Cladistics and classification. Timber Press: Portland, Oregon, 752p.

Burt S (2004) Essential oils: their antibacterial properties and potential applications in foods-a review. Int J Food Microbiol. 94: 223-253.

Candan F, Unlu M, Tepe B, Daferera D, Polissiou M, Sökmen A, Akpulat HA (2003) Antioxidante and antimicrobial activity of the essencial oil and methanol extracts of Achillea millefolium subsp. millefolium Afan.(Asteraceae). J Ethnopharmacol. 87: 215-220.

Carneiro FB, Irinaldo-Junior D, Lopes PQ, Macedo RO (2010) Variação da quantidade de $\beta$-cariofileno em óleo essencial de Plectranthus amboinicus (Lour.) Spreng., Lamiaceae, sob diferentes condições de cultivo. Rev Bras Farmacogn. 20: 600-606.

De Sant'anna JR, Franco CC, Miyamoto CT, Cunico MM, Miguel OG, Côcco LC, Yamamoto $\mathrm{Cl}$, Junior CC, de CastroPrado MA (2009) Genotoxicity of Achillea millefolium essential oil in diploid cells of Aspergillus nidulans. Phytother Res. 23: 231-235.

Duarte MCT Figueira GM, Sartoratto A, Rehder VL, Delarmelina C (2005) Anti-Candida activity of Brazilian medicinal plants. J Ethnopharmacol. 97: 305-311.

Kindlovits S, Németh E (2012) Sources of variability of yarrow (Achillea spp.) essential oil. Acta Aliment. 41: 92103.

Lorenzi H, Matos FJA (2002) Plantas medicinais no Brasil: nativas e exóticas. 1a ed. Editora Plantarum, São Paulo.

Messias MCTB, Menegatto MF, Prado ACC, Santos BR, Guimarães MFM (2015) Uso popular de plantas medicinais e perfil socioeconômico dos usuários: um estudo em área urbana em Ouro Preto, MG, Brasil. Rev Bras PI Med. 17: 76-104.

Mohammadhosseini $M$, Akbarzadeh A, HashemiMoghaddam H (2016a) Gas chromatographic-mass spectrometric analysis of volatiles obtained by HSSPMEGC-MS technique from Stachys lavandulifolia and evaluation for biological activity: a review. J Essent OilBear Plant. 19: 1300-1327.

Mohammadhosseini $M$, Akbarzadeh A, HashemiMoghaddam H, Nafchi AM, Mashayekhi HA, Aryanpour A (2016b.) Chemical composition of the essential oils from the aerial parts of Artemisia sieberi by using conventional hydrodistillation and microwave assisted hydrodistillation: a comparative study. J. Essent. Oil-Bear Plant. 19: 32-45.

Mohammadhosseini M, Sarker SD, Akbarzadeh A (2017) Chemical composition of the essential oils and extracts of Achillea species and their biological activities: A review. J Ethnopharmacol. 199: 257-315.

Morelli F, Ferarrese L, Munhoz CL, Alberton O (2017) Antimicrobial activity of essential oil and growth of Ocimum basilicum (L.) inoculated with mycorrhiza and humic substances applied to soil. Genet Mol Res. 16: gmr16039710.
Nadim MM, Malik AA, Ahmad J, Bakshi SK (2011) The essential oil composition of Achillea millefolium $\mathrm{L}$. cultivated under tropical condition in India. World J Agric Res. 7: 561-565.

Nemeth E (2005) Essential oil composition of species in the genus Achillea. J Essent Oil Res. 17: 501-512.

Oliveira TF, Ferreira JS, Boa Sorte PMF, Reis VM, Baldani JI, Schwab S (2009) Concentração Inibitória Mínima (CIM) de antibióticos para oito estirpes de bactérias diazotróficas da Coleção de Culturas da Embrapa Agrobiologia, Seropédica: Embrapa Agrobiologia, $16 \mathrm{p}$.

Oliveira AC, Gonzaga C, Costa R, Damaceno Q, Garbaccio J (2013) Desafios e perspectivas para a contenção da resistência bacteriana na óptica dos profissionais de saúde. Rev Eletrôn Enfer. 15: 747-754.

Orav A, Arak E, Raal A (2006) Phytochemical analysis of the essential oil of Achillea millefolium $\mathrm{L}$. from various European countries. Nat Prod Res. 20: 1082-1088.

Orth M, Czygan F-C, Dedkov VP (1999) Variation in essential oil composition and chiral monoterpenes of Achillea millefolium s.i. from Kaliningrad. J Essent Oil Res. 11: 681687.

Pino JA, Rosado A, Fuentes V (1998) Chemical composition of the leaf oil of Achillea millefolium L. grown in Cuba. J Essent Oil Res. 10: 427-428.

Ribeiro DI, Alves MS, Faria MGI, Svidzinski TIE, Nascimento IA, Ferreira BP, Ferreira GA, Gazim ZC (2010) Determinação da atividade antifúngica dos óleos essenciais de Curcuma longa L. (Zingiberaceae) e de Achillea millefolium (Asteraceae) cultivadas no Noroeste do Paraná. Arq Ciênc Saúde UNIPAR. 14: 103-109.

Rohloff J, Skagen EB, Steen AH, Iversen TH (2000) Production of yarrow (Achillea millefolium L.) in Norway: essential oil content and quality. J Agric Food Chem. 48: 6205-6209.

Salvagnini LE, Migliato KF, Isaac VLB, Correa MA, Salgado HRN, Pietro RCLR (2006) Evaluation of efficacy of preservatives associated with Achillea millefolium $\mathrm{L}$. extract against Bacillus subtilis. Braz J Microbiol. 37: 75-77.

Sartoratto A, Machado ALM, Delarmelina C, Figueira GM, Duarte MCT, Hehder VLG (2004) Composition and antimicrobial activity of essential oils from aromatic plants used in Brazil. Braz J Microbiol. 35: 275-280.

Simões CMO, Schenkel EP, Gosmann G, Mello JCP, Mentz LA, Petrovick PR. (2004) Farmacognosia: da planta ao medicamento. 5 ed. rev. atual. Porto Alegre/Florianópolis: UFRGS; UFSC, p. 467-495.

Singh O, Khanam Z, Misra N, Srivastava MK (2011) Chamomile (Matricaria chamomilla L.): an overview. Pharmacogn Rev. 5: 82-95.

Stevanovic ZD, Pljevljakušic D, Ristic M, Šoštaric I, Kresovic $M$, Simic I, Vrbnièanin S (2015) Essential oil composition of Achillea millefolium Agg. populations collected from saline habitats in Serbia. J Essent Oil-Bear Plant. 18: 1343-1352.

Sweetman SC (2002) Martindale: The complete drug reference. 33 ed., Pharmaceutical Press, Londres.

Tzakou O, Pitarokili D, Chinou IB, Harvala C (2001) Composition and antimicrobial activity of the essential oil of Salvia ringens. Planta Med. 67: 81-83. 